Filozofska fakulteta, Univerza v Ljubljani

Slovenija

andreja.trenc@ff.uni-lj.si

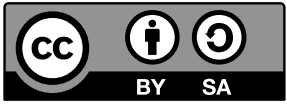

\title{
AULA INTERNACIONAL PLUS 1
}

Corpas, J., García, E., Germendía, A. (2020): Aula Internacional Plus 1 (učbenik + delovni zvezek). Barcelona: Difusión. ISBN/EAN: 9788418032189, mehka vezava, 232 strani, 35 EUR

\section{SPLOŠNE METODOLOŠKE ZNAČILNOSTI}

Aula Internacional Plus 1 je učbenik za začetno učenje španščine na osnovni ravni A1 po Skupnem evropskem jezikovnem okviru. Namenjen je odraslim, ki španščino usvajajo kot tuji jezik, vsebinsko in metodološko pa se prilagaja tudi mlajšim odraslim, torej srednješolski publiki, za katero je ponudba ciljanih učbenikov španščine na trgu še razmeroma pičla. Avtorji učbenika, ki se dopolnjuje z višjimi stopnjami istoimenske zbirke, zasledujejo sporazumevalni pristop, znotraj tega pa na dejavnosti osredotočen pristop, ki poudarjeno razvija zmožnost sporazumevanja v španščini za dosego konkretnih, najbolj neposrednih sporazumevalnih ciljev ob sočasni skrbi za jezikovno pravilnost in ustreznost. Tako učbenik uravnoteženo razvija zmožnosti razumevanja ter sporočanja in sporazumevanja ter usvajanje različnih jezikovnih (oblikoslovno-skladenjske prvine, besedišče, diskurzivne in pragmatične funkcije) ter nejezikovnih sredstev (državljanska in medkulturna zavest). Metodološko je usklajen s sodobnimi spoznanji strok, ki opredeljujejo didaktiko španščine kot tujega jezika, saj učenje z uresničevanjem dejavnosti v (pol)izvornih položajih osmišlja, približuje učenčevi lastni izkušnji, ter ga spodbuja k udejanjanju jezikovnih ciljev, ki tudi opredeljujejo tematske enote v učbeniku: osebno predstavitev, pozdrave, obvladovanje tujih jezikov, prostočasne dejavnosti, opisovanje bivanjskega okolja, predmetov, tržnih dobrin, osebnostnih in telesnih značilnosti, dnevnega urnika in pogostih opravil, naročanje hrane in pijače, nakupovanje, načrtovanje potovanj ter upovedovanje preteklih izkušenj in zmožnosti. Poudarjen je tudi humanistični pristop, ki prek dejavnosti opazovanja in primerjave sistematično razvija večjo kulturno ozaveščenost, strpnost in pozitivno vrednotenje razlik med lastno kulturo in špansko govorečimi. Zadnja izdaja učbeniške zbirke glede na prejšnje ob neokrnjeni vsebini ponuja didaktične posodobitve: digitalizacijo gradiv (učbenika z rešitvami in didaktičnimi 
napotki za učitelja, delovnih listov, shematskih prikazov, slušnih in pisnih besedil v različicah ter video posnetkov, preizkusov za (samo)vrednotenje znanja, dodatne vaje), več tematsko posodobljenih in kulturno raznolikih besedil, ter večji poudarek na usvajanju besedja v skladu s sodobnim, na besedišče osredinjenim pristopom (enfoque léxico).

Učbenik z dejavnostmi na spletu ter strnjeno izčrpno strukturo devetih enot omogoča obvladljivo in prilagodljivo didaktično sredstvo, ki se z jasnim ciljem - usvojiti vstopno znanje španščine - zlahka prilagaja različnim paletam potreb ter učnih resničnosti v srednjih šolah in gimnazijah (medpredmetno povezovanje, vključevanje IKT, občasno samostojno učenje, razpoložljivo število ur za 2. ali 3. tuji jezik).

\section{ZGRADBA}

Učbenik uvaja predenota, namenjena seznanjanju z osnovnimi pojmi, abecedo in števniki, najznačilnejšimi kulturnimi vidiki prek primerjave s sorodnimi pojmi v drugih tujih jezikih (učenec je z lastnim predznanjem zastopan kot učno sredstvo). Osrednji del učbenika predstavlja devet tematskih enot, ki se osredinjajo na že omenjene vsebinske cilje in se po notranji dinamiki smiselno stopnjujejo tako, da vsako enoto uvaja vidna ali besedilna iztočnica, sledijo naloge razumevanja ter več odprtih dejavnosti, ki temeljijo na izražanju in sporazumevanju s spontano rabo usvojenih jezikovnih vidikov in vodijo do uresničitve zaključnega projekta. Projekt, ki sklene sleherno enoto, je zasnovan kot cilj, ki določa obseg jezikovnih vsebin v skladu z mednarodnimi in domačimi učnimi načrti (učni načrt Cervantesovega instituta ter slovenski učni načrt za srednje šole ter gimnazije): oblikoslovno-skladenjske, denimo, perifraze za izražanje obveze tener que in haber que z nedoločnikom, besedišča, kot so barve in oblačila, izgovorjavo nezvenečih soglasnikov, ter tudi prečne (transverzalne) veščine, saj je projekt zasnovan kot skupinsko delo v sodelovanju, spodbuja dialog, diskusijo in kritičnost, tudi pri samostojnem odbiranju relevantnih informacijskih virov, ter (samo)vrednotenje uporabnosti znanja. Poglavja so vsebinsko ter po obsegu (štirinajst strani) uravnotežena, kar zdržema omogoča enakomeren ritem učenja. Enakovredno so zastopane vaje iz bralnega in slušnega razumevanja ter pisnega in ustnega izražanja oz. sporazumevanja, ki se smiselno prek posebnih grafičnih kazalk razširjajo z ustreznimi dodatnimi dejavnostmi na spletu ali v dodatku (»delovnem zvezku«).

Enoto uvaja razdelek Empezar (Začeti) z izbrano vidno iztočnico, ki s povezano nalogo prikliče ter vsebinsko umesti (pred)znanje v osrednjo temo enote. Prenovljena likovna oprema s svežim, sodobnim in za mlade ustreznim grafičnim jezikom povsem učinkovito nagovarja ciljno publiko, vzdržuje zanimanje in osredotočenost ter podpira tako preglednost enote kot učne vsebine, saj ne služi zgolj dekoraciji, temveč tudi tematski dopolnitvi nalog in razumevanju, priklicu ali pomnjenju snovi. Prvi razdelek Comprender (Razumeti) na dveh straneh podaja daljše besedilo, namenjeno seznanjanju 
S slovničnimi prvinami, besediščem in diskurznimi sredstvi v sobesedilu raznolikih besedilnih tipologij praktičnega (pisnega) sporazumevanja: brošur, elektronske pošte, oglasov. Pozornost je posvečena širokemu naboru raznovrstnih besedil in učnih strategij bralnega razumevanja in učenja besedišča, saj spletna različica vseh vključenih besedil vsebuje tudi ustrezno označeno ciljno besedišče najpogostejših besednih zvez ali kolokacij, kar je redka, a smiselna posodobitev tudi v učbenikih za začetno učenje španščine z namenom razvijati večjo občutljivost za usvajanje zapletenejših izrazov. Priložen je krajši slovarček Construimos el léxico (Gradimo besedišče s pomočjo strategije skupinjenja), ki ga učenec samostojno dopolnjuje. Na spletni strani založbe je vsako besedilo mogoče prebrati tudi $\mathrm{v}$ drugi različici španščine in ga nadgraditi $\mathrm{z}$ dodatnimi branji, $\mathrm{s}$ čimer učenec pridobi še več kakovostnega jezikovnega vnosa. Umetnostna besedila, ki bi ob praktično-sporazumevalnih lahko ponudila prostor za učenje brezčasnih kulturnih vidikov, spodbudo za tvorno in ustvarjalno izražanje, ter priprave na maturitetni tematski sklop iz književnosti, v učbeniku niso zastopana, zato bo izbor bržkone prepuščen profesorju. Slušni posnetki so kakovostni in obvladljivi, saj vsebujejo polizvorna besedila s prilagojeno, a dovolj naravno dinamiko izgovora za zadosten slušni vnos, ter spletno nadgradnjo v drugi dialektalni različici za dodatno ozaveščanje družbeno-jezikovne raznolikosti špansko govorečega področja. Razdelek Explorar y reflexionar (Raziskati in razmisliti) obsega štiri strani, posveča pa se usvajanju slovnice in besedišča prek razumevanja rabe ciljnih jezikovnih sredstev v sobesedilu. Podajanje vsebin je implicitno, saj učenec prek opazovanja določenega slovničnega pravila ali načela ustreznosti besedišča sobesedilu (krajšemu pisnemu dokumentu) sam izpelje pravilo rabe, svojo podmeno pa nato praktično preveri; povzame informacijo iz besedila, se odzove na tematsko iztočnico, tvori dialog, razvršča podatke, ali pa pravilo preveri s pomočjo nazornih shematičnih preglednic slovničnih povzetkov in razlag v dodatku učbenika.

Prav induktivno usvajanje slovnice in besedišča, osredinjeno na tvorjenje jezikovnih pomenov v procesu sporazumevanja predstavlja eno od temeljnih metodoloških odlik pričujočega učbenika. Dodan je tudi ilustriran tematski slovar uporabljenega besedišča (léxico) - nepogrešljiv pripomoček pri seznanjanju z osnovnimi izrazi. Spletna razširitev Cápsula de fonética (Glasoslovna kapsula) pa je namenjena samostojnemu učenju pravilne izgovorjave glasov prek posnetih zgledov. Razdelek Practicar y comunicar (Vaditi in se sporazumevati) tvorijo tri strani raznolikih, k sporazumevanju usmerjenih vaj za utrjevanje jezikovnih vsebin, ki pa jih učenec strne v celoto znanj, jih poveže s povsem osebno izkušnjo v svoje sobesedilo v končni dejavnosti ali projektu (kvizu, plakatu, diskusiji). Enoto sklene razdelek Video (Video), v katerem učenec s pomočjo posnetih reportaž, intervjujev, igranih odlomkov odkriva, razišče in primerja kulturno-civilizacijske vidike špansko govorečih dežel s svojo kulturo, krepi medkulturno ozaveščenost ter zanimanje za različne običaje in aktualne globalne razmere v okoljih, v katerih se španščina razvija. S simpatično in sodobno zasnovo v duhu globalne kulturne resničnosti (rasna in spolna enakost, medkulturna družba) pa posnetki nagovarjajo h kritičnemu razmisleku 
ali razgovoru v razredu. Zastopanost v posnetkih predstavljenih zemljepisnih prostorov je nekoliko v prid evropskemu okolju oz. Španiji, kar bo glede na odprtost spletnega gradiva z nekaj založniške občutljivosti za uravnoteženost zastopanih kulturnih kontekstov in dodatno učiteljevo razlago mogoče učinkovito premostiti. Dodatno poglavje Más ejercicios (Več vaj) tvori delovni zvezek, namenjen samostojnemu utrjevanju snovi iz tematskih enot, nadgradnji dela v razredu ter razvoju sporazumevalnih spretnosti, prek jezikovnih vaj s poudarjenim slovničnim ozadjem, ki se zdijo smiselne v procesu seznanjanja $\mathrm{z}$ razmeroma zapleteno špansko glagolsko fleksijo. K ustreznim vajam nazorno napotijo kazalke v enotah. Tudi tu ilustracije učinkovito podpirajo vsebine.

Razdelek Más gramática (Več slovnice) vsebuje sistematičen pregled obravnavanih slovničnih pravil prek preglednic, pojasnil in številnih zgledov sporazumevalne rabe. Smiselno je urejen po slovničnih kategorijah, iskanje pa olajšajo kazalke na posamezno pojasnilo v ustreznem poglavju, kjer se slovnična tema pojavlja. Izbor zastopanih glagolskih spregatev sedanjika ter sestavljenega preteklika (pretérito perfecto compuesto) je skladen z ravnjo A1, saj je z njima mogoče ubesediti kar najširšo paleto osnovnih časovnih razmerij: trenutna in prihodnja dejanja in načrte ter pretekle izkušnje.

Učbenik dopolnjuje bogato didaktično gradivo za učitelja, ki je v celoti digitalizirano, v različnih komponentah pa povsem nadomešča priročnik v klasičnem smislu; itinerario digital (digitalna učna pot) vsebuje napotila za ustrezno nadgradnjo dejavnosti z dodatnimi interaktivnimi pripomočki, ki so na voljo na spletni strani založbe: alternativa digital (integrirane sporazumevalne spretnosti v najsodobnejših digitalnih učnih okoljih moodle, Padlet, ...), fichas proyectables (interaktivni učni listi z jezikovnimi igrami), examen autocorregible (izpit za samopreverjanje znanja s sprotno povratno informacijo o usvojenem znanju), rešitve vaj, ter številne dodatne dejavnosti, ki profesorju prihranijo čas in olajšajo delo v digitalni učilnici.

\section{SKLEP}

Učbenik Aula Internacional Plus 1 ustreza smernicam za poučevanje španščine na osnovni ravni A1 ter učnemu načrtu španščine v srednji šoli in gimnaziji, saj vključene vsebine in sporazumevalni pristop sistematično omogočajo usvajanje jezika na osnovni ravni. Učbenik s poudarjeno medkulturno noto pri učenju jezika odlikuje sodoben, raznolik način podajanja tematik in učinkovito vpletanje IKT, ter zlasti vključevanja dijaka z lastno osebno in kulturno izkušnjo v središče procesa učenja, zato se $\mathrm{z}$ vidika sodobnega poučevanja tujega jezika zdi, da ga bodo z zanimanjem vzeli v roko tako starejši najstniki kot tudi profesorji španščine ne glede na izkušnje. 